\title{
Is there still room to explore cyclodextrin glycosyltransferase- producers in Brazilian biodiversity?
}

\author{
ANDREA C.S.M GOMES ${ }^{1}$, SAMUEL R. DOS SANTOS ${ }^{1,2}$, MAYCON C. RIBEIRO ${ }^{1}$, PEDRO V.L. \\ CRAVO $^{3}$, JOSÉ DANIEL G. VIEIRA ${ }^{1}$, KEILI M.C. DE SOUZA ${ }^{1}$ and ANDRE C. AMARAL ${ }^{1}$ \\ ${ }^{1}$ Instituto de Patologia Tropical e Saúde Pública, Universidade Federal de Goiás, \\ Rua 235, s/n, Setor Universitário, 74605-050 Goiânia, GO, Brazil \\ ${ }^{2}$ Instituto de Ciências Biomédicas II, Universidade de São Paulo, Av. Prof. Lineu Prestes, 1374, 05508-900 Butantã, SP, Brazil \\ ${ }^{3}$ Instituto de Higiene e Medicina Tropical, Universidade Nova de Lisboa, Rua da Junqueira, 100, 1349-008 Lisboa, Portugal
}

Manuscript received on August 30, 2017; accepted for publication on October 30, 2017

\begin{abstract}
In the present work, different Brazilian biomes aiming to identify and select cyclodextrin glycosyltransferase-producer bacteria are explored. This enzyme is responsible for converting starch to cyclodextrin, which are interesting molecules to carry other substances of economic interest applied by textile, pharmaceutical, food, and other industries. Based on the enzymatic index, 12 bacteria were selected and evaluated, considering their capacity to produce the enzyme in culture media containing different starch sources. It was observed that the highest yields were presented by the bacteria when grown in cornstarch. These bacteria were also characterized by sequencing of the $16 \mathrm{~S}$ rRNA region and were classified as Bacillus, Paenibacillus, Gracilibacillus and Solibacillus.
\end{abstract}

Key words: Cyclodextrin glycosyltransferase, cyclodextrin, Brazilian biodiversity, bioprospection.

\section{INTRODUCTION}

Despite the belief of some scientists that cyclodextrins (CD) have lost their biotechnological interest, the finding of novel and better bacteria able to produce the enzyme to convert starch into CDs is still the focus of constant research (Atanasova et al. 2008, Duchêne and Bochot 2016, Goh et al. 2017). This search becomes interesting when exploring the biodiversity aiming to identify these microorganisms.

CDs are cyclic nanostructures presenting a hydrophobic interior, suitable of forming

Correspondence to: Andre Correa Amaral

E-mail: amaral.nanobio@gmail.com complexes with various substances of commercial interest for the food, chemical, cosmetic and pharmaceutical industries (Duchêne and Bochot 2016, Es et al. 2016). CDs are formed by converting starch substrates by the enzyme cyclodextrin glycosyltransferase (CGTase, EC 2.4.1.19). These enzymes are produced by bacteria of different genera, among them, Bacillus, Paenibacillus, Klebsiella, Thermoanaerobacterium, Thermoanaerobacter, and Actinomycetes (Han et al. 2013).

Brazil is considered an important source of the world's biodiversity (Matias et al. 2009, Pylro et al. 2014) and, thus, it is expected to find bacteria with biotechnological potential, including 
those CGTase-producers. In the soil, various microorganisms can be found that can be exploited for their biotechnological potential (Martins et al. 2013). Considering the different environmental conditions, such as temperature, salinity, nutrients and water conditions, these microorganisms need to adapt their metabolic requirements to survive in these adverse conditions (Fuka et al. 2009), in many cases, expressing genes of biotechnological importance. Despite the enormous potential, much of this biodiversity has not yet been explored to discover products that could be used to improve the quality of life of the population. The Brazilian biodiversity still presents a diversity of species that can be found in biotechnological products.

The objective of the present work was, therefore, to bioprospect CGTase-producer bacteria in soil samples from different regions of Brazil.

\section{MATERIALS AND METHODS}

\section{COLLECTION AND PROCESSING OF SAMPLES}

Soil samples were collected from different cultivars in the states of Goiás (Central-Midwest region), Minas Gerais (Southeast region) and Rio Grande do Sul (South region) as shown in Table I. The choice for these samples is because of the probability of finding good CGTase-producers bacteria in soils with starch-rich food crops cultivars. Samples of these soils were collected at $20 \mathrm{~cm}$ depth, placed in sterile plastic bags and stored at room temperature until processing.

\section{SCREENING OF BACTERIA PRODUCING CGTase}

One gram of each soil sample was screened for removal of impurities, such as pieces of plants and small stones, and was inoculated into a tube containing $10 \mathrm{~mL}$ of sterilized water. The tubes were kept at $25{ }^{\circ} \mathrm{C}$ for 1 hour to dissolve the soil grains and incubated for 10 minutes at $80^{\circ} \mathrm{C}$. After vigorous shaking for 1 minute, a $100 \mu 1$ aliquot of each sample was seeded in triplicates into Petri dishes containing the culture medium described by Nakamura and Horikoshi (1976). After 48 hours of incubation at $30^{\circ} \mathrm{C}$, the colonies that presented the halo of starch degradation were isolated and stored in $15 \%$ glycerol at $-20{ }^{\circ} \mathrm{C}$.

\section{INVESTIGATION OF CGTase PRODUCTION}

The CGTase production by the isolated bacteria was determined calculating the Enzymatic Index (EI). Thus, the EI was calculated, which evaluates the enzymatic production of the bacterium as a value found dividing the diameter of the halo by the diameter of the colony formed in the culture medium containing phenolphthalein (adapted from Florencio et al. 2012 ).

After 24, 48 and 72 hours incubation at 30 ${ }^{\circ} \mathrm{C}$, the diameters of each halo formed by each colony were measured to obtain the EI, which consists of dividing the halo diameter by the colony diameter. The presence of the halo on the plate is indicative of the presence of the CGTase because of the discoloration of the medium as a result of

TABLE I

Plant cultivation and collection sites of soil samples in different regions of the states of Goiás (GO), Minas Gerais (MG) and Rio Grande do Sul (RS).

\begin{tabular}{cccc}
\hline Region & City/ State & Cultivar & Geolocation \\
\hline Atlantic forest & Guanhães/ MG & Okra & $18^{\circ} 40^{\prime} 32.3^{\prime} \mathrm{S} 42^{\circ} 46^{\prime} 27.6^{\prime} \mathrm{W}$ \\
Atlantic forest & Guanhães/ MG & Banana & $18^{\circ} 40^{\prime} 45.3^{\prime} \mathrm{S} 42^{\circ} 46^{\prime} 30.3^{\prime \prime} \mathrm{W}$ \\
Atlantic forest & São João Evangelista/ MG & Sweet potato & $18^{\circ} 33^{\prime} 56.3^{\prime} \mathrm{S} 42^{\circ} 45^{\prime} 47.8^{\prime} \mathrm{W}$ \\
Brazilian cerrado & Silvânia/ GO & Cassava & $16^{\circ} 41^{\prime} 49.0^{\prime} \mathrm{S} 48^{\circ} 37^{\prime} 14.6^{\prime} \mathrm{W}$ \\
Brazilian cerrado & Serro/ MG & Corn & $18^{\circ} 28^{\prime} 36.4^{\prime} \mathrm{S} 43^{\circ} 29^{\prime} 53.7^{\prime \prime} \mathrm{W}$ \\
Pampa gaucho & Gravataí/ RS & Carrot & $29^{\circ} 56^{\prime} 05.1^{\prime} \mathrm{S} 51^{\circ} 01^{\prime} 52.8^{\prime \prime} \mathrm{W}$ \\
\hline
\end{tabular}


the complexion of the phenolphthalein with the cyclodextrin formed (Kochko and Hamon 1990). For comparison of the best CGTase-producer as a function of the EI, the value obtained after 72 hours was used.

To correlate the substrate with CGTase production capacity, $2 \%$ of each different starch substrates were added to the medium: P.A. starch, potato starch, cornstarch, wheat flour, and glucose. After being inoculated, the Petri dishes were incubated at $30{ }^{\circ} \mathrm{C}$ for 72 hours in triplicate for each substrate.

MORFOTINTORIAL BACTERIA ANALYSIS AND 16S rRNA BACTERIA IDENTIFICATION

The bacteria were characterized by the Gram Differential Coloring Technique (Coico 2005).

The CGTase-producer bacteria were selected based on the EI over 1.5 and had their $16 \mathrm{~S}$ ribosomal RNA (rRNA) region gene sequenced as an attempt to identify the bacterial species. The DNA of the selected isolates was extracted using the Wizard Purification kit (Promega, Wisconsin, USA), following the manufacturer's instructions. The $16 \mathrm{~S}$ rRNA gene sequence was amplified by Polymerase Chain Reaction (PCR) using oligonucleotides 27F (5'-AGAGTTTGATCMTGGCTCAG-3') and 1541R (5'-GAAGAGGTGATCCAGCC-3'). The amplified product was purified using the
PureLink PCR Purification Kit (Invitrogen, California, USA), according to the manufacturer's instructions. The sequencing of the gene was performed using the oligonucleotides described above and the oligonucleotides 519R (5'GWATTACCGCGGCKGCTG3'), 530F (5'CAGCAGCCGCGGTAATAC3'), 907R (5'CCGTCAATTCMTTTRAGTT3') and 926F (5'AACACCAAAGGAATTGACGG3'). The BigDye terminator cycle sequencing ready reaction Kit and the ABI3750 sequencer(Applied Biosystems, Foster City, CA) were used. The sequences obtained were compared to the reference sequences of the GenBank database, through Blast and aligned in the ClustalX program. The phylogenetic tree was designed through the Mega 6 program, 1000 bootstraps, Neighbor-Joining method.

\section{RESULTS}

SCREENING OF BACTERIA PRODUCING B-CGTase IN THE SOIL AND THEIR INDEXES ENZYME

The first screening for the CGTase-producers bacteria was performed plating the soil aliquots in plates containing phenolphthalein as an indicator of the presence of the CGTase enzyme. The colonies were identified when the degradation halo was observed, as presented in Figure 1. Thus, selected colonies were seeded four successive times to guarantee isolating the colonies.
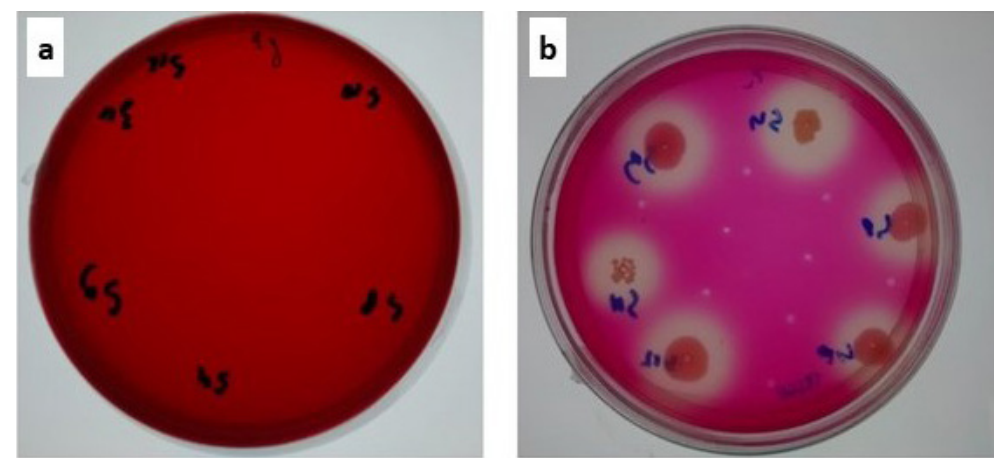

Figure 1 - Culture medium containing phenolphtaleine (a) as indicator of starch degradation by CGTase-producer bacteria. The clear halo around bacteria colony (b) is a result of the cyclodextrin-phenolphtaleine complex. 
TABLE II

Selected CGTase-producer bacteria based in the enzimatic index using the cut off of $\mathbf{1 . 5}$.

\begin{tabular}{ccc}
\hline City/ State & Cultivar & $\begin{array}{c}\text { Atributted } \\
\text { codification }\end{array}$ \\
\hline Silvânia/ GO & Cassava & 1MAGO \\
Guanhães/ MG & Okra & 2HOMG \\
Gunhães/ MG & Okra & 3 HOMG \\
Gunhães/ MG & Banana & 4 BNMG \\
Guanhães/ MG & Okra & 5HOMG \\
Silvânia/ GO & Cassava & 6 MAGO \\
Silvânia/ GO & Cassava & 7 MAGO \\
Gravataí/ RS & Carrot & 8 HORS \\
Gravataí/ RS & Carrot & 9 HORS \\
Gravataí/ RS & Carrot & $10 \mathrm{HORS}$ \\
Serro/ MG & Corn & $11 \mathrm{MIMG}$ \\
Serro/ MG & Corn & $12 \mathrm{MIMG}$ \\
\hline
\end{tabular}

*The attributed code was defined considering the number of the strain, two letter of the cultivar Portuguese name and the federal state code. ${ }^{\#}$ GO: Goiás, MG: Minas Gerais, RS: Rio Grande do Sul.

This methodology results in the selection of 29 colonies, isolated to be screened based on their enzymatic index (EI). The bacteria that did not show growth halo in the maximum time of 72 hours at $30{ }^{\circ} \mathrm{C}$ were discarded. Of these, 12 were selected from the cut off 1.5 calculated by the EI using PA starch as a substrate and also using different sources of starch as substrates. As can be noted in Table II, the bacteria were isolated from different cultivars, such as cassava $(n=03)$, carrot $(n=03)$, corn $(n=$ $02)$, okra $(n=03)$, and banana $(n=01)$.

\section{EVALUATION OF THE BEST SUBSTRATE FOR CGTase PRODUCTION}

The selected bacteria had a diverse ability to assimilate different carbon sources as shown in Table III. They are able to use three of four sources evaluated to convert the starch to $\beta$-cyclodextrin.

Unlike the other substrates used and shown in Figure 2a, c, d, in Petri dishes containing the minimal glucose-containing medium as the carbon source (Figure $2 b$ ), bacterial growth occurred but no halo formation was detected, pointing out that glucose was not used by the enzyme CGTase.

\section{BACTERIA CHARACTERIZATION}

All selected bacteria were characterized as Gram positive. From the molecular sequencing of the $16 \mathrm{~S}$ rRNA region, it was possible to identify the species of eight isolates grouped in the genus Bacillus, Paenibacillus, Solibacillus, and Gracilibacillus, according to the phylogenetic diagram presented in Figure 3. The selected CGTase-producer reported in Figure 3 were deposited in the GenBank database using the accession numbers $2 \mathrm{HOMG}$ (KX762301); 3HOMG (KX762302); 4BNMG

TABLE III

Enzimatic index using a variety of starch substrates.

\begin{tabular}{cccccc}
\hline \multirow{2}{*}{ Cultivar } & & \multicolumn{4}{c}{ Enzimatic Index (media \pm SD) } \\
\cline { 3 - 5 } & & Potato & Corn & Wheat & Glucose \\
\hline Banana & 4BNMG & $\mathbf{4 . 5}( \pm \mathbf{0 . 4})$ & $3.1( \pm 0.6)$ & $3.2( \pm 0.2)$ & 0.0 \\
Cassava & 1MAGO & $4.0( \pm 1.0)$ & $\mathbf{7 . 3}( \pm \mathbf{1 . 1})$ & $\mathbf{7 . 4}( \pm \mathbf{4 . 0})$ & 0.0 \\
Cassava & 6MAGO & $4.6( \pm 2.9)$ & $\mathbf{9 . 2}( \pm \mathbf{1 . 4})$ & $3.9( \pm 0.3)$ & 0.0 \\
Cassava & 7MAGO & $5.5( \pm 0.7)$ & $5.4( \pm 0.5)$ & $4.5( \pm 0.6)$ & 0.0 \\
Carrot & $\mathbf{8 H O R S}$ & $2.4( \pm 0.3)$ & $2.4( \pm 0.6)$ & $2.2( \pm 0.3)$ & 0.0 \\
Carrot & 9HORS & $2.4( \pm 0.4)$ & $2.3( \pm 0.3)$ & $2.1( \pm 0.1)$ & 0.0 \\
Carrot & $\mathbf{1 0 H O R S}$ & $3.0( \pm 0.3)$ & $2.3( \pm 0.9)$ & $1.8( \pm 0.3)$ & 0.0 \\
Corn & $\mathbf{1 1 M I M G}$ & $3.4( \pm 0.3)$ & $\mathbf{4 . 6}( \pm \mathbf{0 . 3})$ & $3.2( \pm 0.3)$ & 0.0 \\
Corn & $\mathbf{1 2 M I M G}$ & $\mathbf{3 . 5}( \pm \mathbf{0 . 1})$ & $3.0( \pm 0.3)$ & $2.1( \pm 0.1)$ & 0.0 \\
\hline
\end{tabular}

"Starch P.A. used as positive control. The numbers in bold are used to highlight the highest Enzimatic Index values. 

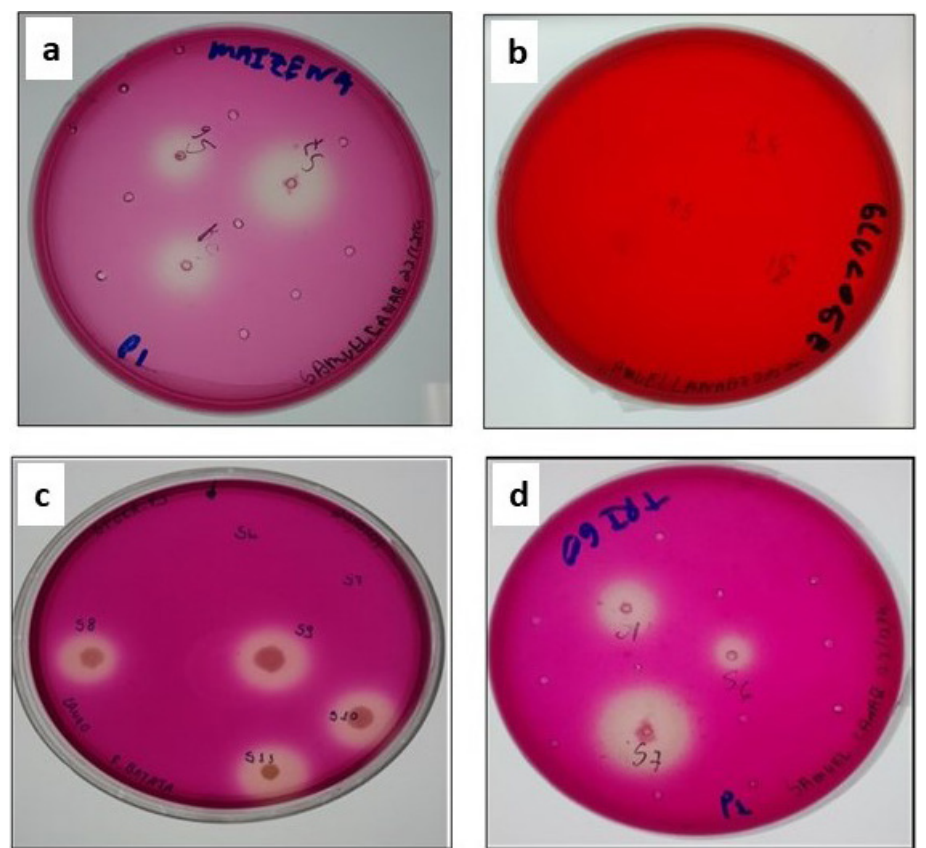

Figure 2 - Petri dishes after 24 hours showing degradation halos in the culture medium containing different starch as carbon source. (a) Cornstarch; (b) Glucose; (c) Potato; (d) Wheat.

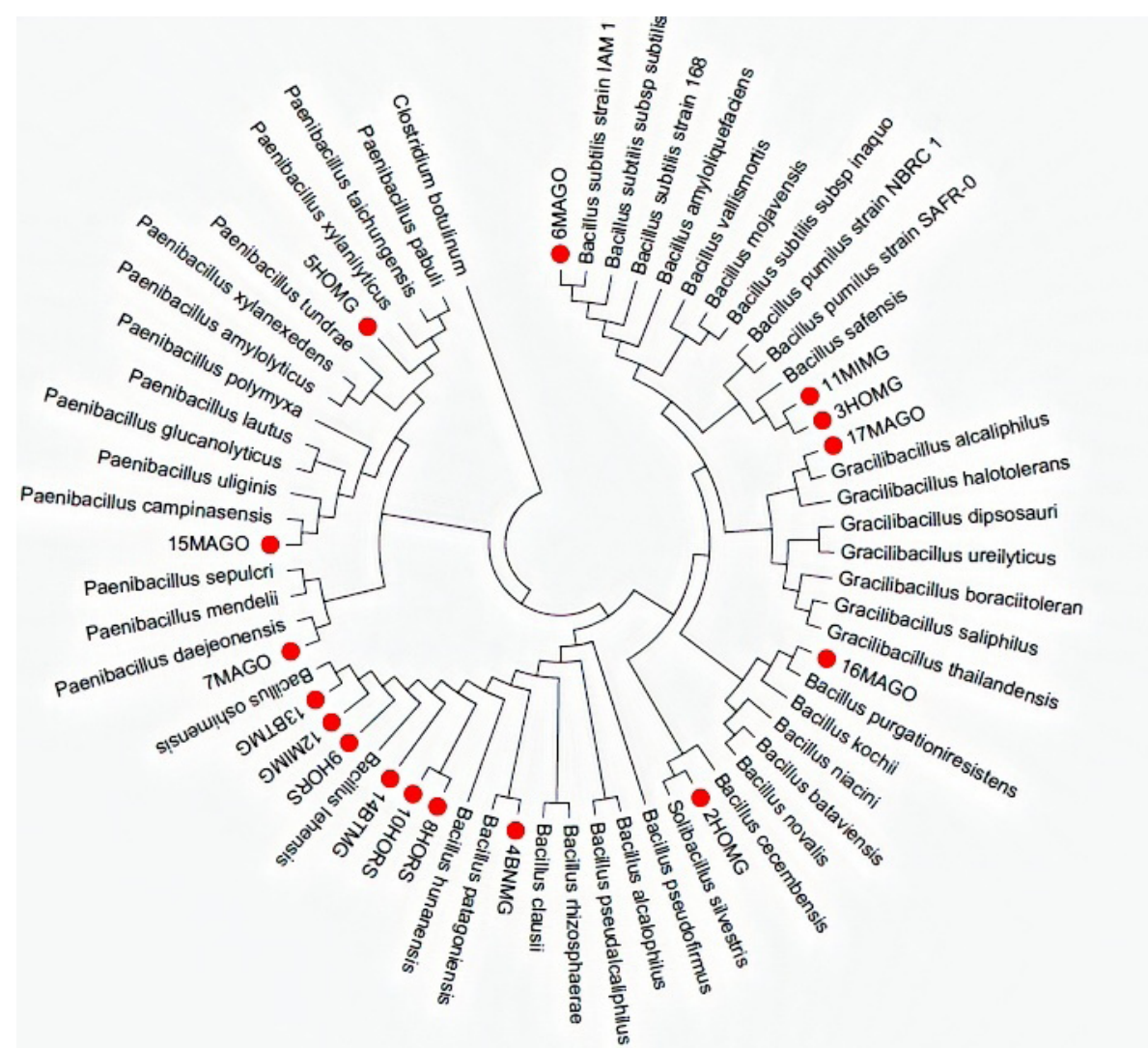

Figure 3 - Phylogenetic diagram constructed using the 16S rRNA molecular sequencing of the selected bacteria using the Neighbor-Joining with 1000 replicates. 
(KX762303); 5HOMG (KX762304); 6MAGO (KX762305); 7MAGO (KX762306); 8HORS (KX762307); 9HORS (KX762308); 10HORS (KX762309); 11MIMG (KX762310); 12MIMG (KX762311); 13BTMG (KX762312); 14BTMG (KX762313); 15MAGO (KX762314); 16MAGO (X762315); 17MAGO (KX762316).

\section{DISCUSSION}

Considering this search for CGTase-producer bacteria, it can be noted that there is still room to bioprospect this enzyme in the Brazilian biomes (Martins et al. 2013). It was possible to select 12 bacteria that presented satisfactory values for the enzymatic index greater than or equal to 1.5 (Florencio et al. 2012).

Screening of the bacteria was performed considering the enzymatic production capacity pointed out by forming a clear halo around the colony in the starch-rich medium containing the phenolphthalein dye. As the bacterium produces the enzyme CGTase to use starch as an energy source, they produced $\mathrm{CD}$ as a metabolic product. The $\mathrm{CD}$ produced forms a complex with the phenolphthalein, rescuing it from the culture medium, which results in a clear halo around the colony (Mäkelä et al. 1987). Although other reasons are also involved in the change in color of the medium, such as $\mathrm{pH}$ change, phenolphthalein is still a good indicator of the presence of CGTase producing bacteria.

The selected bacteria were also evaluated for their ability to use other sources of starch as a substrate for CGTase conversion. Cornstarch showed the best yield. This may be because of the greater amount of amylopectin, promoting CGTase activity. Substrates rich in amylopectin molecules containing the $\alpha-1.6$ linkages are better for CGTase activity (Bonilha et al. 2006). This versatility of bacteria to convert starch from different sources becomes attractive for getting $\mathrm{CD}$ from leftovers of food industries, such as that from corn processing (Higuti et al. 2004, Mora et al. 2012).

When culture medium containing glucose was used as the sole carbon source, formation of complexation halos in the medium was not detected, only bacterial growth was noted. Glucose was described as an inhibitor of CGTase producing by bacteria, acting as a control for gene expression for this enzyme (Nishida et al. 1997). This was observed for all 12 bacteria selected when cultured with glucose.

In an attempt to identify the selected bacteria, the $16 \mathrm{~S}$ rRNA region was sequenced. This is a conserved region of the bacterial genome, responsible for encoding part of the bacterial ribosome (Böttger 1989, Srinivasa et al. 2015). Since many of these sequences are available in genomic databases, it is possible to identify both genus and species level after molecular sequencing using specific primers (Srinivasa et al. 2015).

Through composing the phylogenetic diagram, it was possible to identify the bacteria as belonging to the genus Bacillus, Paenibacillus, Gracilibacillus, and Solibacillus. These findings are in concordance with data in the literature (Han et al. 2013). Making a phylogenetic diagram using evolutionary algorithms based on these sequences allows for the genetic derivation between species because of gene mutations in this region (Weisburg et al. 1991). An interesting fact was to have selected the bacterium Bacillus patagoniensis in the soil of the banana cultivar. This bacterium was first described by researchers who isolated it from the rhizosphere of the Atriplex lampa plant in eastern Patagonia in Argentina (Olivera et al. 2005), about 2.500 miles distant from the region in which it was isolated in Brazil.

\section{CONCLUSIONS}

The biological diversity found in Brazil still suggests a niche to be explored for the search 
of living beings that can be exploited to obtain biotechnological products. The present work shows the importance of exploring the microbiota of Brazilian biomes, since many bacteria that are good CGTase-producers were isolated and identified in the soil samples. New research and new legislation should be created to ensure the study and protection of Brazilian genetic heritage.

\section{ACKNOWLEDGMENTS}

The authors would like to thank the Universidade Federal de Goiás for support for developing the present study. Also, Fundação de Apoio à Pesquisa do Estado de Goiás (FAPEG) for Samuel's scholarship support and the Conselho Nacional de Desenvolvimento Científico e Tecnológico (CNPq) for financial support. Authors Andrea Maroclo, Samuel Rodrigues and Maycon Carvalho equally contributed to this paper.

\section{REFERENCES}

ATANASOVA N, PETROVA P, IVANOVA V, YANKOV D, VASSILEVA A AND TONKOVA A. 2008. Isolation of novel alkaliphilic bacillus strains for cyclodextrin glucanotransferase production. Appl Biochem Biotechnol 149: $155-167$.

BONILHA PRM, MENOCCI V, GOULART AJ, POLIZELI MLTM AND MONTI R. 2006. Cyclodextrin glycosyltransferase from Bacillus licheniformis: optimization of production and its properties. Braz $\mathrm{J}$ Microbiol 37(3): 317-323.

BÖTTGER EC. 1989. Rapid determination of bacterial ribosomal RNA sequences by direct sequencing of enzymatically amplified DNA. FEMS Microbiol Lett 53(1-2): 171-176.

COICO R. 2005. Gram staining. Curr Protoc Microbiol Appendix 3: Appendix 3C.

DUCHÊNE D AND BOCHOT A. 2016. Thirty years with cyclodextrins. Int J Pharm 514: 58-72.

ES I, RIBEIRO MC, SANTOS-JÚNIOR SR, KHANEGHAH AM, RODRIGUEZ AG AND AMARAL AC. 2016. Production of cyclodextrin glycosyltransferase by immobilized Bacillus sp. on chitosan matrix. Bioprocess Biosyst Eng 39(10): 14871500 .

FLORENCIO C, COURI S AND FARINAS CS. 2012. Correlation between agar plate screening and solid-state fermentation for the prediction of cellulose production by Trichoderma strains. Enzyme Res 2012: 793708.

FUKA MM, ENGEL M, HAGN A, MUNCH JC, SOMMER M AND SHLOTER M. 2009. Changes of diversity pattern of proteolytic bacteria over time and spare in an agricultural soil. Microbiol Ecol 57: 391-401.

GOH KM, LIEW KJ, CHAI KP AND ILLIAS RM. 2017. Use of megaprimer and overlapping extension PCR (OE-PCR) to mutagenize and enchance cyclodextrin glucosyltransferase (CGTase) function. In: Reeves A (Ed), In vitro Mutagenesis: Methods and Protocols, Methods in Molecular Biology. Springer Science+Business Media, New York 1498: 385-396.

HAN R, LI J, SHIN H, CHEN RR, DU G, LIU L AND CHEN J. 2013. Recent advances in discovery, heterologous expression, and molecular engineering of cyclodextrin glycosyltransferase for versatile applications. Biotechnol Adv 32(2): 415-428.

HIGUTI IH, SILVA PA AND NASCIMENTO AJ. 2004. Studies on alkalophilic CGTase-producing bacteria and effect of starch on cyclodextrin-glycosyltransferase activity. Braz Arch Biol Technol 47(1): 135-138.

KOCHKO A AND HAMON S. 1990. A rapid and efficient method for the isolation of restrictable total DNA from plants of the genus Abelmoschus. Plant Mol Biol Rep 8(1): 3-7.

MÄKELÄ M, KORPELA T AND LAAKSO S. 1987. Colorimetric determination of beta-cyclodextrin: two assay modifications based on molecular complexation of phenolphtalein. J Biochem Biophys Methods 14(2): 85-92.

MARTINS LF ET AL. 2013. Metagenomic analysis of a tropical composting operation at the São Paulo Zoo Park reveals diversity of biomass degradation functions and organisms. PLoS ONE 8(4): e61928.

MATIAS F, BONATTO D, PADILLA G, RODRIGUES MFA AND HENRIQUES JAP. 2009. Polyhydroxyalkanoates production by actinobacteria isolated from soil. Can J Microbiol 55: 790-800.

MORA MM, SÁNCHEZ KH, SANTANA RV, ROJAS AP, RAMÍREZ HL AND TORRES-LABANDEIRA JJ. 2012. Partial purification and properties of cyclodextrin glycosiltransferase (CGTase) from alkalophilic Bacillus species. Springerplus 1(1): 61.

NAKAMURA N AND HORIKOSHI K. 1976. Characterization and some culture conditions of a cyclodextrin-glycosyltransferase-producing alkalophilic Bacillus sp. Agric Biol Chem 40(4): 753-757.

NISHIDA T, NAKAMURAA, MASAKI H AND UOZOMI T. 1997. Regulation of cyclodextrin glucanotransferase synthesis in Bacillus ohbensis. FEMS Microbiol Lett 149(2): 221-226.

OLIVERA N, SIÑERIZ F AND BRECCIA JD. 2005. Bacillus patagoniensis sp. nov., a novel alkalitolerant bacterium 
from the rhizosphere of Atriplex lampa in Patagonia, Argentina. Int J Syst Evol Microbiol 55(PI1): 443-447.

PYLRO VS ET AL. 2014. Brazilian Microbiome Project: revealing the unexplored microbial diversity-challenges and prospects. Microb Ecol 67(2): 237-241.

SRINIVASAN R, KARAOZ U, VOLEGOVA M, MACKICHAN J, KATO-MAEDA M, MILLER S,
NADARAJAN R, BRODIE EL AND LYNCH SV. 2015. Use of 16S rRNA gene for identification of a broad range of clinically relevant bacterial pathogens. PLoS ONE 10(2): e0117617.

WEISBURG WG, BARNS SM, PELLETIER DA AND LANE DJ. 1991. 16S ribosomal DNA amplification for phylogenetic study. J Bacteriol 173(2): 697-703. 